\title{
HYDROCARBON SOURCE ROCK SAMPLING IN PEARY LAND 1980
}

\author{
F. Rolle
}

\section{Introduction}

The Peary Land region in North Greenland (fig. 31) contains a sequence of Lower Palaeozoic sediments which is probably more than $4 \mathrm{~km}$ thick (Dawes, 1976; Christie \& Peel, 1977; Hurst, 1979; Christie \& Ineson, 1979; Hurst \& Surlyk, 1980; Ineson \& Peel, 1980; Surlyk, Hurst \& Bjerreskov, 1980). From Early Cambrian to Wenlock the area was divided into a northern turbidite trough and a southern, mainly carbonate platform (fig. 32). The platform seems to have undergone several phases of backstepping to the south, accompanied by expansion of the turbidite basin (fig. 32) (Surlyk et al., 1980). The region was affected by an orogeny of assumed Devonian - early Carboniferous age (Dawes, 1976). Deformation is most intense in northern Johannes V. Jensen Land (fig. 31), where an amphibolite facies is attained along the north coast (Dawes \& Soper, 1973) and decreases southwards, leaving the platform carbonates virtually undeformed. A separate, strongly block-faulted sedimentary basin, the Wandel Sea Basin is present in eastern Peary Land and farther to the south-east (Dawes \& Soper, 1973; Håkansson, 1979). It contains a sequence of Upper Palaeozoic carbonates and Upper Palaeozoic - Mesozoic mainly coarse clastics more than $3 \mathrm{~km}$ thick.

North Greenland like other large Phanerozoic sedimentary basins has long been regarded as interesting from a petroleum geological view point (Henderson, 1976). From 1968 to 1973 Ponderay Polar A/S (a company wholly owned by the Greenarctic Consortium) held a prospecting licence in North Greenland and carried out an aeromagnetic survey and geological field work. Prior to the systematic geological mapping programme initiated by GGU in 1978, the hydrocarbon potential was speculative.

The main aim of the present programme is not to define individual source or reservoir rocks or traps, but rather to establish the regional and stratigraphic distribution of organic matter types, amounts and thermal alterations and diagenetic trends, thus providing a basis for later more detailed investigations.

\section{Earlier investigations}

During the first two years of the North Greenland mapping project in the Peary Land region in 1978 and 1979, it was confirmed that the Cambro-Silurian platform sequence contains several intervals of stinking black limestones, dolomites and shales, and scattered occurrences of bituminous pore-filling were noted. Sampling was made by many of the participating geologists from intervals which appeared interesting, although a systematic and representative sampling was not attempted. Sixty-four samples were analysed for organic content, extractable organic matter, distribution of aliphatic and aromatic hydrocarbons and heterocompounds, and composition of the $\mathrm{C}_{15}+$ hydrocarbons (P. Wrang, personal communication, 1980). The results indicated that mature source rocks are present in the Brøn- 


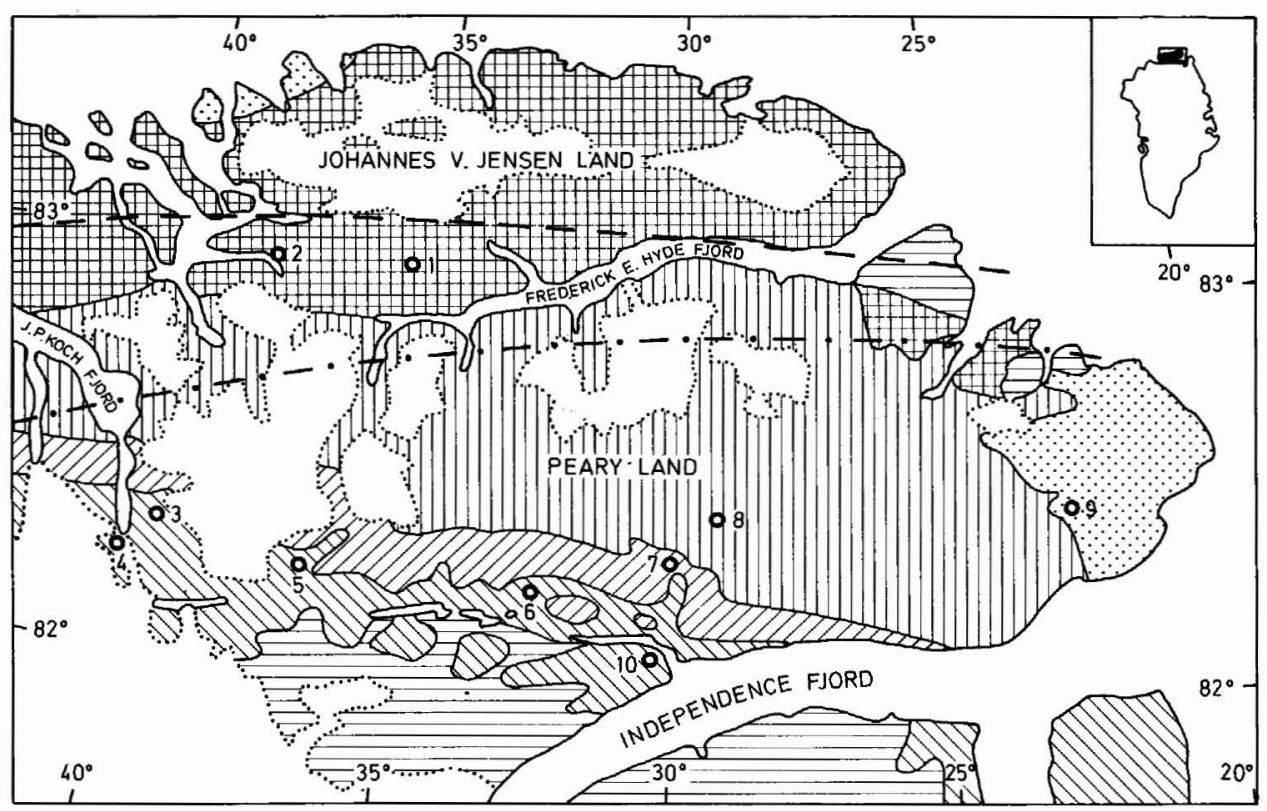

O 2 Locality sampled in 1980

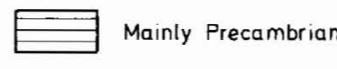

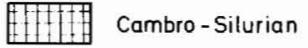

- Harder Fjord

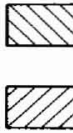

Mainly Cambrian

Mainly Silurian

- Navarana Fjord Fault Zone

Mainly Ordovician

Upper Palaeozoic -

Mesozoic

$\because \ldots \ldots$ Main ice fields

$0 \mathrm{~L}, \quad 1 \quad 1 \quad 100 \mathrm{~km}$

Fig. 31. Simplified geological map of the Peary Land region showing localities sampled for source rock investigations in 1980. The Harder Fjord Fault Zone corresponds roughly to the southern limit of the central fold belt and the Navarana Fjord Fault Zone to the southern limit of the marginal fold belt. Based on maps published by Grønlands Geologiske Undersøgelse (1979; this report) and Surlyk et al. (1980, fig. 1).

lund Fjord Group, while promising samples were found in the Portfjeld Formation, Wandel Valley Formation and the un-named Silurian shale formation (fig. 32). However, the results were in most cases ambiguous because of possible weathering effects, bacterial destruction of hydrocarbons or migration.

\section{Field work 1980}

On this basis a systematic sampling programme was carried out by the author in 1980 . A total of 33 days were spent in the field, and 10 localities were visited (figs 31 \& 32). The major part of the Lower Palaeozoic platform sequence was examined, but detailed investigations were made only in the Brønlund Fjord Group, where the presence of mature source 


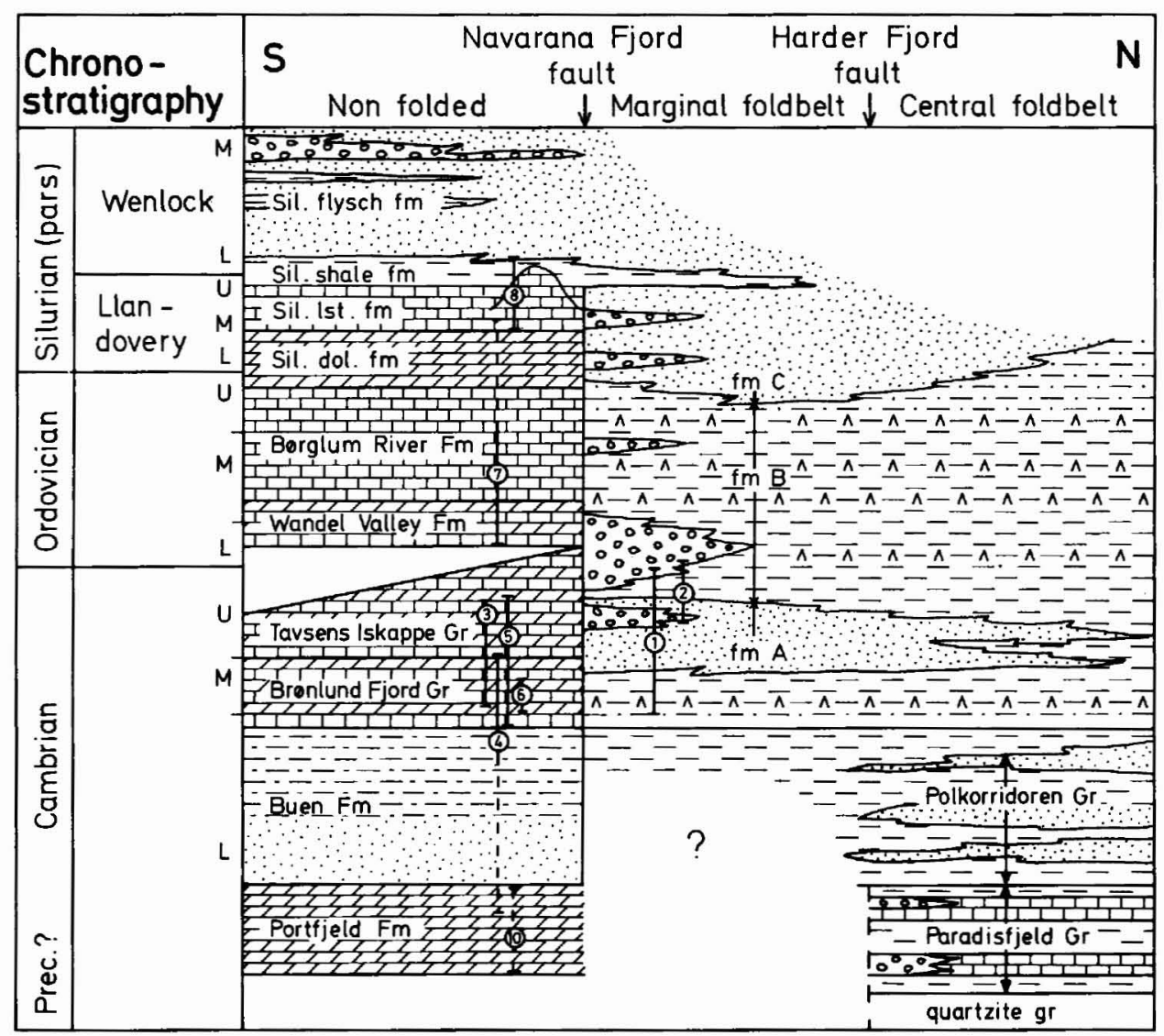

\begin{tabular}{|c|c|c|c|c|c|}
\hline$E$ & Mudstone & $\wedge \wedge \wedge$ & Chert & קיבו1 & Mainly limestone \\
\hline$E \div \div-$ & $\begin{array}{l}\text { Mudstone and } \\
\text { thin turbidites }\end{array}$ & & $\begin{array}{l}\text { Sandstone and } \\
\text { sandy turbidites }\end{array}$ & हद्र & Mainly dolomite \\
\hline$E \div \div]$ & $\begin{array}{l}\text { Siltstone and } \\
\text { sandy mudstone }\end{array}$ & $\because 000$ & Resedimented $\mathrm{cgl}$. & $\oint$ & $\begin{array}{l}\text { Intervals sampled at } \\
\text { each locality }\end{array}$ \\
\hline
\end{tabular}

Fig. 32. Stratigraphy and facies distribution along a N-S transect through Peary Land. The stratigraphic intervals sampled are indicated with numbers referring to the localities shown in fig. 1. Modified from Surlyk et al., 1980, fig. 3.

rocks had been indicated. The Buen Formation was only briefly visited because previous analyses had shown its organic content to be far too low to be of any interest.

The trough-sequence was visited at two localities in the marginal foldbelt (loc. $1 \& 2$, figs $31 \& 32$ ). No analyses had previously been carried out on material from this sequence, but the increasing degree of deformation northwards in the area, combined with the fairly high thermal maturity of organic matter in the southern part of the region, suggested that the 
trough-sediments would be overmature. However, it was considered important to get samples from this part of the sequence as well, in order to evaluate the regional effect of the deformation as well as the types and amounts of organic matter in the sediments.

Locality 9 represents a short visit to a part of the Mesozoic sequence in the Wandel Sea Basin. Here a previously undescribed sequence of about $100 \mathrm{~m}$ of black mudstones was measured and sampled in detail. Dinoflagellates from the mudstones indicate an Aptian (Lower Cretaceous) Age (S. Piasecki, personal communication, 1980), while thin sandstone intervals at the top of the sequence yielded a rich ammonite fauna of Albian (Lower Cretaceous) Age (T. Birkelund, personal communication, 1980).

In all the sections visited, lithological investigations were carried out, and samples were taken for petrophysical and diagenetic studies so that the reservoir properties and trends can be evaluated.

\section{Sampling procedure and laboratory investigations}

Samples collected for organic geochemical analysis were carefully selected in the field to make sure that they were representative of the sampled interval. An attempt was made to take the samples from as far below the surface as possible to reduce the effects of weathering, but in many cases permafrost prohibited digging more than $10-30 \mathrm{~cm}$ into unconsolidated shales, or intense fracturing made it impossible to get unweathered samples even at some depth. The samples were wrapped in aluminium foil to avoid contamination.

Samples are currently being analysed in GGU's organic geochemical laboratory, following a procedure described in detail by Perregaard (1978). Firstly any weathered surfaces are cut away, and immediately before extraction a portion of $150 \mathrm{~g}$ of the fresh sample is ground in a ball mill, and carbonates are removed by acid treatment. Total organic carbon (TOC) is determined by the combustion of carbonate-free, crushed samples in a Leco-furnace. Extractable organic matter (EOM) is found by Soxhlett extraction with dichloromethane, and liquid chromatography is used to separate saturated hydrocarbons, aromatic hydrocarbons and heterocompounds (NSO). Gas chromatography of the $\mathrm{C}_{15}$ hydrocarbons is performed on a Hewlett Packard HP 5850A instrument. Kerogen concentrates from selected samples are being made for optical investigation. Samples collected for lithological studies are being cut and thin sectioned, and core plugs are taken for petrophysical measurements.

\section{Conclusions}

Only a few analytical results are available at the time of writing, but they seem to confirm the presence of mature source rocks in the Lower Palaeozoic platform sequence. The trough sequence north of Frederick E. Hyde Fjord (fig. 31) is rich in organic matter, but does not offer good source potential because it has been overmatured by the thermal effect of the orogenic movements in the region. 


\section{References}

Christie, R. L. \& Ineson, J. R. 1979: Precambrian-Silurian geology of the G. B. Schley Fjord region, eastern Peary Land, North Greenland. Rapp. Grønlands geol. Unders. 88, 63-71.

Christie, R. L. \& Peel, J. S. 1977: Cambrian-Silurian stratigraphy of Børglum Elv, Peary Land, eastern North Greenland. Rapp. Grønlands geol. Unders. 82, 48 pp.

Dawes, P. R. 1976: Precambrian to Tertiary of northern Greenland. In Escher, A. \& Watt, W.S. (edit.) Geology of Greenland, 248-303. Copenhagen: Geol. Surv. Greenland.

Dawes, P. R. \& Soper, N. J. 1973: Pre-Quaternary history of North Greenland. In Pitcher, M. G. (edit.) Arctic Geology. Mem. Amer. Ass. Petrol. Geol. 19, 117-134.

Grønlands geol. Unders. 1979: Report on the 1978 geological expedition to the Peary Land region, North Greenland. Rapp. Grønlands geol. Unders. 88, 94 pp.

Henderson, G. 1976: Petroleum geology. In Escher, A. \& Watt, W. S. (edit.) Geology of Greenland, 488-505. Copenhagen: Geol. Surv. Greenland.

Hurst, J. M. 1979: Uppermost Ordovician and Silurian geology of north-west Peary Land, North Greenland. Rapp. Grønlands geol. Unders. 88, 41-49.

Hurst, J. M. \& Surlyk, F. 1980: Notes on the Lower Palaeozoic clastic sediments of Peary Land, North Greenland. Rapp. Grønlands geol. Unders. 99, 73-78.

Håkansson, E. 1979: Carboniferous to Tertiary development of the Wandel Sea Basin, eastern North Greenland. Rapp. Grønlands geol. Unders. 88, 73-83.

Ineson, J. R. \& Peel, J. S. 1980: Cambrian stratigraphy in Peary Land, eastern North Greenland. Rapp. Grønlands geol. Unders. 99, 33-42.

Perregaard, J. 1978: Establishment of an organic geochemical laboratory in GGU. Rapp. Grønlands geol. Unders. 90, 151-154.

Surlyk, F., Hurst, J. M. \& Bjerreskov, M. 1980: First age-diagnostic fossils from the central part of the North Greenland foldbelt. Nature, 286, 800-803. 